
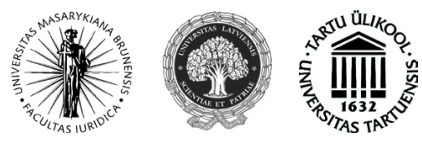

ISSN 1392-6195 (print)

\title{
PROROGATION OF JURISDICTION IN FAMILY-LAW MATTERS: ANALYSIS OF CURRENT NATIONAL LEGISLATION AND INTERNATIONAL TREATIES OF UKRAINE
}

\author{
Yuliya Chernyak \\ Department of Private International Law \\ Institute of International Relations \\ Kyiv National Taras Shevchenko University \\ 36/1 Melnikova str., Kyiv, Ukraine, \\ Tel.: +80444814443 \\ E-mail: kafedra344@ukr.net
}

Received on 13 October, 2014; accepted on 20 November, 2014

doi:10.13165/JUR-14-21-4-09

(I) Introduction. Grounds for ruling of jurisdiction over cases with a foreign element by Ukrainian courts are governed by international treaties and national legal acts of Ukraine. Although the history of private international law proves that it is too difficult to adopt uniform rules on jurisdiction, international conventions seem to be the most effective mechanism for regulation of the different issues of prorogation agreements: its validity, legal effects, recognition and enforcement of judgments resulting from proceedings based on such agreements. Until recently, there has been only one type of international treaties in which Ukraine is party providing the rules on international jurisdiction - multi- and bilateral treaties on legal assistance and legal relations in civil and family matters. Over the last 10 years, Ukraine has become the Contracting State of a number of the Hague Conventions on international protection of children and family relations, all of which contain the uniform rules on

Jurisprudencija/Jurisprudence

(C) Mykolo Romerio universitetas, 2014

(C) Mykolas Romeris University, 2014
ISSN 1392-6195 (print), ISSN 2029-2058 (online) http://www.mruni.eu/lt/mokslo_darbai/jurisprudencija/ http://www.mruni.eu/en/mokslo_darbai/jurisprudencija/ 
international jurisdiction. On September 1, 2005, the Law of Ukraine on Private International Law ${ }^{1}$ entered into force. The Law has three sections on procedural issues: Section XI. Proceedings with Participation of Foreigners; Section XII. Jurisdiction and Execution of Foreign Court Orders, and Section XIII. Recognition and Enforcement of Foreign Court's Judgments. Article 76 of the Law stipulates in what instances Ukrainian courts may initiate the proceedings and try cases with a foreign element, and the first instant is the following: "if the parties chose the jurisdiction of Ukrainian courts over a case with a foreign element by their agreement, save as provided in Article 77 of this Law" (Article 77 regulates exclusive jurisdiction of Ukrainian courts, as stated by Yu. Chernyak).

It is necessary to point that the Law of Ukraine on Private International Law has introduced the most remarkable changes in the regulation of prorogation of jurisdiction on the level of internal legislation. Two procedural codes of Ukraine, in their currently in force versions, the Civil Procedural $\operatorname{Code}^{2}$ and the Commercial Procedural $\mathrm{Code}^{3}$, do not provide any rules on this type of jurisdiction. The Law of Ukraine from July 7, 2010 on the Status of Judges and Judicial System of Ukraine ${ }^{4}$ has removed Article 112 from the Civil Procedural Code - Jurisdiction under the parties consent, according to which the parties on the case had the right to determine territorial jurisdiction of the case in a written agreement, unless exclusive jurisdiction was provided for the case. As a result, application of the legal institution and the legal phenomena "prorogation of jurisdiction" for national civil procedure of Ukraine were terminated. However, there are several laws in Ukraine permitting prorogation of jurisdiction for the cases which are related to private-law relations with a foreign element. They are the stated above Law on Private International Law (p. 1 Art. 76), the Law of Ukraine on Foreign Economic Activity from April 16, 1991 (Art. 38) and the Merchant Shipping Code of Ukraine from May 23, $1995^{6}$ (Art. 8). The rules of these legal acts confirm that jurisdiction agreements are applied for the most part in international trade and commerce.

1 Law of Ukraine on Private International Law. June 23, 2005. Bulletin of Verkhovna Rada of Ukraine. 2005, No 32.

2 Civil Procedural Code of Ukraine. March 18, 2004 [interactive]. [accessed on 2014-10-06]. $<$ http://zakon4.rada.gov.ua/laws/show/1618-15>.

3 Commercial Procedural Code of Ukraine. November 6, 1991 [interactive]. [accessed on 201410-06]. <http://zakon4.rada.gov.ua/laws/show/1798-12>.

4 Law of Ukraine on the Status of Judges and Judicial System of Ukraine. July 7, 2010 [interactive]. [accessed on 2014-10-06]. <http://zakon4.rada.gov.ua/laws/show/2453-17>.

5 Law of Ukraine on Foreign Economic Activity. April 16, 1991. Bulletin of Verkhovna Rada of Ukraine. 1991, No 29.

6 The Merchant Shipping Code of Ukraine. May 23, 1995. Bulletin of Verkhovna Rada of Ukraine. 1995, No 47. 
The doctrine ordinarily determines prorogation agreement as "the agreement on the choice of jurisdiction", "agreement specifying the court to which a party may apply for the protection of his/her rights" . Sometimes it is underlined that the agreement "is applicable in foreign trade and its aim is to grant jurisdiction for the disputes arising from foreign trade to the courts of a certain state and correspondingly to exclude the jurisdiction of the courts of another states". ${ }^{9}$

The main purpose of this statement is to study the rules on prorogation of jurisdiction provided by internal legislation of Ukraine and the mentioned above ratified by Ukraine Hague Conventions, to represent positive features and difficulties in application of these acts and to draw conclusions concerning peculiarities of prorogation of jurisdiction for matters relating to family-law relations. Attention is also paid to the comparative overview of Hague Conventions and some Regulations of the European Union which are considered to be one of the most successful instruments on harmonization of European civil procedure.

Some aspects addressed in this statement were researched by the authors of European Commentaries on Private International Law, particularly, Brussels IIbis Regulation was studied by U. Magnus and P. Mankowski, Professor of Law from University of Amsterdam Jannet A. Pointer; jurisdictional rules provided by the 1996 Hague Convention on the Protection of Children were studied by the Professor of Law from Cardiff Law School Nigel Lowel; a brief overview of jurisdictional rules of the Law of Ukraine on Private International Law 2005 is given in the works of the authors of this Law - Professors of Kyiv National Taras Shevchenko University A.S. Dovgert and V.I. Kysil.

(II) The principle of party autonomy in the field of International Civil Procedure and the institute of jurisdiction of the matters, arising from family-law disputes. The main point of prorogation agreement is that it permits the parties of private-law relations to change non-mandatory provisions on the court jurisdiction and to choose the court that will consider and resolve their dispute(s). In the ideal world, the court determined by consent of the parties should be the most suitable for both of them. Such way of jurisdiction regulation seems to be logic and appropriate, because ordinarily the division of the court competence on civil cases is made in the interests of the parties on the case. That is why rules on prorogation of jurisdiction may be characterized as those which develop the principle of party autonomy and the

7 Boguslavskij, M. M. Mezhdunarodnoe chastnoe pravo. [Boguslavskiy, M. M. Private International Law]. Moskva: Jurist, 1998, p. 353.

8 Lebedev, S. N. Priznanie prorogacionnykh uslovij sdelok $v$ mezhdunarodnoj torgovle. [Lebedev, S. N. Recognition of Prorogation Agreements in International Trade]. Sovietskij ezhegodnik mezhdunarodnojo prava, 1963. Moskva: Nauka, 1965, p. 420.

9 Kejlin, A. D. Sudoustrojstvo i grazhdanskij process kapitalisticheskikc gosudarstv. Ch. 2. [Keylin, A. D. Judicial System and Civil Procedure in Capitalistic States. P. 2]. Moskva: Vneshtorgizdat, 1958 , p. 34 . 
principle of effectiveness of legal remedies. According to the Ukrainian law doctrine, based on the current legislation, these principles presume the right of a person to apply to the court for the protection of his/her rights, freedoms and legitimate interests, the right to choose the jurisdictional forms for consideration and resolution of cases, the demand for review of the cases by the court only on the base of submitted petitions and/or statements ${ }^{10}$. Scientists of the European Union, where jurisdiction agreements have the high level of legal regulation (first of all, thanks to the Regulation Brussels $I^{11}$ ), studied the principle of party autonomy as one of the components of the principle "Disputes should be decided by an appropriate court"12.

It is necessary to recognize that the content of party autonomy is disclosed more widely in scientific works dedicated to the principle lex voluntatis as one of the types of conflicts norms ${ }^{13}$. Such situation may be explained by the fact that the principle of party autonomy has become of great importance for regulation of relations arising from international contract obligations. The extension of the principle over the scope of cross-border litigation is rather a new phenomenon. Therefore, it is no wonder that the meaning and the scope of the mentioned principle in transnational civil procedure is often explored in the comparative-law aspect with its application in international contract law. For example, German scientist H. Shack indicates that while the principle of private autonomy predominates in the sphere of substantive law and autonomy of will is recognized in the international contract law, the autonomy and freedom in the actions of the process participants are restricted, "the parties of the case can't give a judge orders on how he/she is obliged to manage the proceeding, but they have the right to influence on the proceeding in the limits defined by lex fori, - for example they can determine jurisdiction of the court on the dispute by the conclusion of an agreement" ${ }^{14}$. R. Fentiman, the author of the work "International

10 Mizhnarodnij civilnij proces Ukraini: Navchalnij posibnik. Praktikum: za red. S.Ja. Fursi. [International Civil Procedure of Ukraine: Textbook, Practicum. Fursa, S.Ya. (ed.)]. Kiiv: Vidavec Fursa S.Ja.: KNT, 2010, p. 44-45.

11 Regulation No 44/2001/EC of December 22, 2000 on Jurisdiction and the Recognition and Enforcement of Judgments in Civil and Commercial Matters. [2001] OJ of the EC, 16.1.2001.

12 Pointer, J.A.; Burg, E. EU Principles on Jurisdiction and Recognition and Enforcement of Judgments in Civil and Commercial Matters (According to the Case Law of the European Court of Justice). The Hague, The Netherlands: TMC Asser Press, 2004, p. 142.

13 For example, regarding the modern Ukrainian science, it is necessary to point such works: Kisil, V.I. Mizhnarodne privatne pravo: pitannja kodifikacii. [Kysil, V.I. Private International Law: Issues of Codification]. Kiiv: Ukraina, 2000; Dovgert, A. C. Peredmova. Mizhnarodne privatne pravo. Naukovo-praktichij komentar Zakonu. / Za red. doktora juridichnikh nauk, prof. A. Dovgerta. [Dovgert, A.S. Introduction. Scientific and Practical Commentary on the Law of Ukraine on Private International Law. Dr. Prof. A. Dovgert (ed.)]. Kh.: TOV «Odisej», 2008.

14 Shak, Kh. Mezhdunarodnoe grazhdanskoe procesualnoe pravo: Uchebnik. / Perevod s nemeckogo. [Shack, H. International Civil Procedural Law: Textbook (Translation from German)]. M.: Izdatelstvo BEK, 2001, p. 22. 
Commercial Litigation", states that "the principle of party autonomy implies that parties are not only free to agree on which law govern their contract, but also on how their disputes will be settled and by whom" and draws the conclusion that today party autonomy plays a fundamental role in international dispute resolution, and the question of unification of jurisdiction rules only becomes relevant if the parties have not agreed on how and where their disputes will be resolved ${ }^{15}$.

Fixation of the principle of party autonomy in cross-border litigation is the remarkable feature of all actual international treaties unifying the rules on the issue of jurisdiction and the recognition and enforcement of judgments arising from proceedings involving private entities from different countries.

The Principles and Rules of Transnational Civil Procedure (Joint Draft of American Law Institute and UNIDROIT Working Group, 2006) ${ }^{16}$ regulate the question of international jurisdiction in the Principle 2 - "Jurisdiction over Parties", and for the first rule of the principle prescribes the following: Jurisdiction over a party may be exercised by consent of the parties to submit the dispute to the tribunal, subject to restrictions of forum law or international treat $y^{17}$. So, the basic principle of jurisdiction over parties is that ordinarily a court may exercise jurisdiction upon the parties' consent.

Another example of systematization of principles on civil litigation is the document prepared by the expert group under the guidance of Max Planck Institute for Comparative and International Private Law professors Felix Steffek and Hannes Unberath, in cooperation with Hazel Genn, Reinhard Greger and Carrie MenkelMeadow, called Guide for Regulating Dispute Resolution (GRDR): Principles ${ }^{18}$. The first group of these Principles is called "Dispute Resolution Mechanisms" and starts with the Principle A: Choice of Procedure, prescribing that "the regulation of dispute resolution should start with and focus on the parties. Generally, the parties and not the state should choose the dispute resolution mechanism (principle of self-determination or party choice of process) $<\ldots>$ ". A prorogation agreement is not remembered in this Principle directly, because the Principle is formulated wider: it concerns the possibility of the parties to choose the concrete mechanism for decision of the dispute on their own discretion (it can be national court, mediation, consultation, etc.).

15 Fentiman, R. International Commercial Litigation. Oxford University Press, 2010, p. 7.

16 According to the Preamble of the Principles, defining the scope of its application, "These Principles are designed for adjudication of transnational commercial disputes. These Principles may be equally appropriate for the resolution of most other kinds of civil disputes and may be the basis for future initiatives in reforming civil procedure".

17 ALI/UNIDROIT Principles of Transnational Civil Procedure as adopted and promulgated by the American Law Institute at Washington, D.C., U.S.A. May 2004 and by UNIDROIT at Rome, Italy April 2004. Cambridge University Press, 2006, p. 18.

18 Steffek, F.; Unberath, U.; Genn, H.; Greger, R.; Menkel-Meadow, C. Regulating Dispute Resolution. ADR and Access to Justice at the Crossroads. Oxford and Portland, Oregon, 2013. 
Secondly, the Principle suggests an important thesis which should lie in the basis of any system of rules for international jurisdiction on civil cases - interests of the parties of the dispute must be surely taken into account at formulation of rules on mechanisms of dispute resolution.

(III) International treaties unifying rules on prorogation of jurisdiction. Today the rules of international jurisdiction, including jurisdiction under choice of court agreements, are successfully unified in a few multilateral international legal instruments. It should be noted that the subject scope of many of these instruments covers civil and commercial cases and does not include family-law matters. For example, Regulation No 44/2001 of 22 December 2000 on Jurisdiction and the Recognition and Enforcement of Judgments in Civil and Commercial Matters (Brussels I) was applied, before the entry into force of the Regulation No $4 / 2009^{19}$, only for one type of matters arising from family-law relations - matters relating to maintenance. Similar provisions concerning the subject scope are contained in the Lugano Convention of 30 October 2007 on Jurisdiction and the Recognition and Enforcement of Judgments in Civil and Commercial Matters ${ }^{20}$. According to Art. 2 of the Hague Convention of 30 June 2005 on Choice of Court Agreements, this Convention shall not apply to an exclusive choice of court agreements to which a natural person acts primarily for family purposes, and it is not applied for the matters on maintenance obligations, other family-law matters, including matrimonial property regimes and other rights or obligations arising out of marriage or similar relationships ${ }^{21}$.

Indeed, the first-ever international legal acts with the uniform jurisdictional rules provided application of prorogation agreement only for civil and commercial matters where the conclusion of such agreement was a well-established practice. As a result, the issues of this type of jurisdiction were examined for a long period of time exceptionally in attachment to commercial agreements ${ }^{22}$. The development of party autonomy in family-law matters was restrained - foremost because in the most countries family relations are regulated not by non-mandatory, but by imperative norms and autonomy of will, as the principle for regulation of family relations is possible only by severe requirements.

19 Regulation No 4/2009/EC of December 18, 2008 on Jurisdiction, Applicable Law, Recognition and Enforcement of Decisions and Cooperation in Matters Relating to Maintenance Obligations. [2009] OJ of the EC, 10.1.2009.

20 Convention of October 30, 2007 on Jurisdiction and the Recognition and Enforcement of Judgments in Civil and Commercial Matters (Lugano Convention). [2007] OJ of the EC, 21.12.2007.

21 Convention of June 30, 2005 on Choice of Court Agreements [interactive]. [accessed on 201410-06]. <http://www.hcch.net/index_en.php?act=conventions.text\&cid=98>.

22 Smith De Bruin, B.L., M. Transnational Litigation. Jurisdiction and Procedure. Thomson Round Hall, 2008, p. 10. 
On the other hand, the analysis of universal and regional agreements adopted in the field of international family law and international civil procedure during the last decade certifies expressly the tendency for application of the principle of party autonomy - both for regulation of family-law relations with a foreign element and for resolution of procedural questions concerning the settlement of disputes arising from these relations. The Hague Conference on Private International Law and the European Union have chosen such way: taking into account specificity of international family-law disputes, the most appropriate method for regulation of procedural issues, including international jurisdiction of such disputes, is to adopt separate international legal acts on these issues. So, the Hague Convention on Jurisdiction, Applicable Law, Recognition, Enforcement and Co-operation in Respect of Parental Responsibility and Measures for the Protection of Children of 1996 (Art. 10) (further - the Hague Convention 1996) ${ }^{23}$ and the Regulation No 2201/2003 of 27 November 2003 Concerning Jurisdiction and the Recognition and Enforcement of Judgments in Matrimonial Matters and the Matters of Parental Responsibility, repealing Regulation EC No 1347/2000 (further - the Brussels IIbis) ${ }^{24}$ (Art. 12) provide for the unified rules on prorogation of jurisdiction for matters on the protection of the person and property of the child. The Hague Convention of 23 November 2007 on the International Recovery of Child Support and Other Forms of Family Maintenance ${ }^{25}$ (Art. 20) (further - the Hague Convention 2007) and the Regulation No 4/2009 of 18 December 2008 on Jurisdiction, Applicable Law, Recognition and Enforcement of Decisions and Cooperation in Matters Relating to Maintenance Obligations (Art. 4) regulate choice of court agreements for disputes relating to maintenance obligations.

The analysis of the mentioned international legal acts allows defining different possible variants of prorogation of jurisdiction in family-law matters. Each of these variants is researched below.

(IV) Jurisdiction of a court before which a defendant appears. This is a special form of prorogation of jurisdiction, the so-called implicit agreement of the parties

23 Convention on Jurisdiction, Applicable Law, Recognition, Enforcement and Co-operation in Respect of Parental Responsibility and Measures for the Protection of Children of October 19, 1996 [interactive]. [accessed on 2014-10-06]. <http://www.hcch.net/index en.php?act=conventions.text\&cid=70>; Law of Ukraine on the Accession to the Convention (September 14, 2006). Bulletin of Verkhovna Rada of Ukraine. 2006, No 43.

24 Regulation No 2201/2003/EC of November 27, 2003 Concerning Jurisdiction and the Recognition and Enforcement of Judgments in Matrimonial Matters and the Matters of Parental Responsibility, Repealing Regulation (EC) No 1347/2000. [2003] OJ of the EU, L 338, Vol. 46, 23 December 2003.

25 Convention of November 23, 2007 on the International Recovery of Child Support and Other Forms of Family Maintenance [interactive]. [accessed on 2014-10-06]. <http://www.hcch. net/index_en.php?act=conventions.text\&cid=38>; Law of Ukraine on the Ratification of the Convention. January 11, 2013. Official Bulletin of Ukraine, 2013, No 12. 
about jurisdiction of the case, when a plaintiff files action in the state, with which now neither he nor a defendant is connected by the place of residence, but the defendant enters into a process without contesting the jurisdiction of the court seized of the proceedings. As the ECJ has noted in its preliminary ruling concerning interpretation of Article 18 of the Brussels Convention on jurisdiction, recognition and enforcement of judgments in civil and commercial matters, in this case "the consent of both parties to submit a dispute to a particular forum is presumed to appear from their conduct in the following sense: if the plaintiff submits a dispute to a court, and the defendant appears and does not contest this court's jurisdiction, both parties are presumed to have agreed to submit the dispute to this forum"26. This type of international jurisdiction is provided in the Hague Convention on the International Recovery of Child Support and Other Forms of Family Maintenance 2007 (p. 1 Art. 20): a decision made in one Contracting State ("the State of origin") shall be recognized and enforced in other Contracting States if the respondent has submitted to the jurisdiction either expressly or by defending on the merits of the case without objecting to the jurisdiction at the first available opportunity. The Hague Convention of 2007 has taken this rule from the Hague Convention on the Recognition and Enforcement of Decisions Relating to Maintenance Obligations (p. 3 Art. 7) ${ }^{27}$ and has specified a judicial term within the limits of which a defendant can contest the jurisdiction - "at the first available opportunity". Thus, it can be concluded that it is possible to declare that the court has no jurisdiction on the early stages of civil procedure - before the presentation of arguments regarding an issue essential to the case (for example, the arguments may be directed for disproof of legal grounds of the claim on maintenance recovery - denial of fact of the existence of family relations and, accordingly, existence of the obligation to pay maintenance).

Within the context of prorogation by the appearance of the defendant, both parties may benefit from the Convention's generosity as to the choice of forum and both parties may run a risk. The plaintiff runs the risk that the defendant appears and (successfully) contests the jurisdiction of the court, and the defendant runs the risk of being tempted by the plaintiff's choice of court, thereby submitting to a court which he would not otherwise have chosen. Such peculiarity of application of the rule of p. 1 Art. 20 of the Hague Convention 2007 raises the importance of obligations of the advocates for the parties. For instance, the defendant's advocate has 1) to take into account circumstances of the case and to determine what will be better for his client - to submit the chosen by the plaintiff jurisdiction or to contest it; 2) to explain the client what procedural actions should he/she do - to raise a plea or to enter an appearance, and what are legal consequences of such actions.

26 Case 48/84, Spitzley v. Sommer. European Court reports [1985], p. 00787.

27 Convention of October 2, 1973 on the Recognition and Enforcement of Decisions Relating to Maintenance Obligations. 1021 UNTS 209. 
(V) Jurisdiction based on the agreement in writing by the parties. The internal national legislation of the most states contains an imperative norm in accordance to which prorogation agreements should be in writing. This rule is considered to be appropriate, especially from the practical point of view. The purpose of the rule was determined by the ECJ - "to ensure legal certainty and that the parties have given their consent"28.

The Law of Ukraine on Private International Law does not provide any rules concerning the formal requirements of the prorogation agreement. The demand for the agreement on jurisdiction in writing is prescribed by the multilateral CIS Convention on Legal Assistance and Legal Relationships in Civil, Family and Criminal Matters, Adopted in Minsk in 1993 (dated Januar 22, 1993, ratified by Ukraine on November 10, 1994) ${ }^{29}$, the CIS Agreement on the Order for Resolution Disputes Arising from Economic Activity, Adopted in Kyiv in 1992 (dated March 22, 1992, ratified by Ukraine on December 19, 1992) ${ }^{30}$ and bilateral treaties on legal assistance in civil and family matters with some states (for example, Poland, Lithuania, Moldavia, Estonia, Georgia, Latvia, Uzbekistan, Vietnam, Turkey, Cuba and North Korea). But all these legal instruments do not regulate important issues, such as the following: what does it mean "in writing"? Should it be the document signed by the parties? May communication between the parties by electronic means be equivalent to "writing"? Certain answers for these questions are stated in the Hague Convention on Choice of Court Agreements of 2005 (Art. 3), the regulation Brussels I (Art. 23), the Regulation № 4/2009 (Art. 4), but Ukraine is not a party to these treaties.

The Hague Convention 2007, ratified by Ukraine in 2013, has the uniform rule on jurisdictional agreements for one of the most widespread categories of family-law cases - cases on international recovery of maintenance. Pursuant to p. e) Art. 20 (p. 1) of the convention, a decision made in one Contracting State ("the State of origin") shall be recognized and enforced in other Contracting States if, except in disputes relating to maintenance obligations in respect of children, there has been agreement to the jurisdiction in writing by the parties. Ukraine has not made any reservations concerning this rule, because it corresponds with provisions of p. 1) Art. 76 of the Law of Ukraine on Private International Law and even details it defining the form of prorogation agreements.

Family-law cases are one of the most widespread cases in the practice of Ukrainian courts, but many of these cases involve parties from the states with which Ukraine has not already concluded international treaties on the issues of international civil procedure. That is why the possibility to ground the Ukrainian court's jurisdiction

28 Case 150/80, Elefanten Schuh v. Jacqmain. ECR [1981], p. 01671.

29 CIS Convention on Legal Assistance and Legal Relationships in Civil, Family and Criminal Matters. January 22, 1993. Official Bulletin of Ukraine, 2005, No 44.

30 CIS Agreement on the Order for Resolution Disputes Arising from Economic Activity. March 20, 1992. Official Bulletin of Ukraine, 2005, No 12. 
by means of prorogation agreement is determined more often on the base of Art. 76 (point 1, part 1) of the Law of Ukraine on Private International Law. For example, in one of the cases, the citizen of Ukraine initiated proceedings in Oleksandrivskiy local court of Kirovograd region for maintenance recovery in respect of her child; she brought an action on the citizen of UAR. In relation to the question of jurisdiction, the court applied the Law of Ukraine on Private International Law, particularly point 1 of part 1 of Art. 76 (because Ukraine does not have any bilateral treaty on legal assistance with UAR, and UAR is not a Contracting State of the Hague Convention 2007 $)^{31}$. Another example is the decision of Pecherskiy district court in Kyiv on the case on termination of parental responsibility, where the plaintiff - mother of the child - was the citizen of Ukraine, and the defendant - father of the child - had domicile and citizenship of Canada. Again, as in the above mentioned case, the court decided to apply Art. 76 (point 1, part 1) of the Law of Ukraine on Private International Law and even gave the plaintiff additional period for submission of the written agreement on jurisdiction of Ukrainian courts. Because it was not submitted, the court declined to hear the case, returned the plaintiff her statement of claim and recommended to apply to appropriate court ${ }^{32}$.

(VI) Jurisdiction accepted by the parents (holders of parental responsibility). This type of jurisdiction is stipulated in the regulation Brussels IIbis (p. 1 Art. 12) and in the Hague Convention of 1996 (Art. 10). It means the following: courts exercising jurisdiction on an application for divorce, legal separation or marriage annulment shall have jurisdiction in any matter relating to parental responsibility connected with that application where (a) at least one of the spouses has parental responsibility in relation to the child and (b) the jurisdiction of the courts has been accepted expressly or otherwise in an unequivocal manner by the spouses and by the holders of parental responsibility at the time the court is seized, and is in the superior interests of the child.

Indeed, this rule is a combination of two types of jurisdiction - prorogation of jurisdiction and jurisdiction forum connexitatis. That is why researchers of the regulation Brussels IIbis highlight that the principle of procedural economy is the main important argument for the opportunity for the court seized of the divorce to be able to rule on parental responsibility ${ }^{33}$ and indicate the jurisdiction under the regulation Brussels IIbis (p. 1 Art. 12) and the Hague Convention of 1996 (Art. 10) as "one-stop" jurisdiction ${ }^{34}$.

31 Decision of Oleksandrivskiy Local Court of Kirovograd Region from May, 13, 2013. Case № 398/3580/13-ц [interactive]. <http://reyestr.court.gov.ua/>.

32 Decision of Pecherskiy District Court in Kyiv from November, 22, 2010. Case № 2-8170/2010 [interactive]. <http://reyestr.court.gov.ua/>.

33 Magnus, U.; Mankowski, P. European Commentaries on Private International Law. Brussels IIbis Regulation. SELP, 2012, p. 146.

34 Lowel, N. The 1996 Hague Convention on the Protection of Children. Family Law. 2012, p. 49. 
The study of these articles shows that jurisdiction of the court seized of an application for divorce (legal separation or marriage annulment) does not determine jurisdiction over matters relating to parental responsibility automatically. Extension of the divorce jurisdiction presupposes the fulfillment of certain requirements. First of all, this jurisdiction needs acceptance by spouses -parents of a child (holders of parental responsibility). This requirement is the main ground for the classification of such jurisdiction as one of the types of prorogation of jurisdiction. Unlike the Hague Convention of 1996 (Art. 10), the regulation Brussels IIbis (p. 1 Art. 12) specifies the way and the period of time for the acceptance of jurisdiction - "accepted expressly or otherwise in an unequivocal manner", "at the time the court is seized". It is noticeable that the objective of the agreement between parents (holders of parental responsibility) is limited, since it is concentrated on jurisdiction of the court to hear the question of parental responsibility.

The extension of the jurisdiction of the court seized of a divorce (legal separation or marriage annulment) to the case on parental responsibility is temporary in nature. The jurisdiction shall cease as soon as the judgment allowing or refusing the application for divorce, legal separation or marriage annulment has become final or the proceedings on the case have come to an end for another reason. This rule is also necessary to interpret from the above stated principle on procedural economy. The reason justifying concentration of the jurisdiction is that the court seized of the divorce is considered to have the opportunity to research and evaluate all the circumstances of the married life of the spouses and, therefore, be seized as well for the questions on parental responsibility. However, these reasons cease its significance after the divorce (legal separation or marriage annulment) has been granted.

The key point of the jurisdictional rule under the regulation Brussels IIbis (p. 1 Art. 12) and in the Hague Convention of 1996 (Art. 10) is the compliance of the accepted jurisdiction with the superior interests of the child. This issue is explored and determined by the court. Of course, it is not easy to imagine the situation when all other requirements provided by the rule are present but the court, nevertheless, orders to decline jurisdiction over parental responsibility. However, it is the fair statement by Ulrich Magnus and Peter Mankowski, authors of the commentary on the regulation Brussels IIbis, that future case law will probably produce some examples where the superior interests of the child, as interpreted by the divorce court, results in the court declining to exercise jurisdiction over parental responsibility ${ }^{35}$.

(VII) Conclusion. Summarizing the above said, it is necessary to note that the gradual development of the prorogation of jurisdiction based on the principle of party autonomy is the essential characteristic feature of the modern international civil procedure as the jurisdictional form for the resolution of family-law disputes. 
The most remarkable changes in the prorogation agreements regulation in Ukraine took place by the entry into force in 2005 of the Law of Ukraine on Private International Law.

The Hague Conventions in which Ukraine is a party specify three variants of prorogation of jurisdiction in family-law matters: the first one - the respondent submits to the jurisdiction either expressly or by defending on the merits of the case without objecting to the jurisdiction; the second one - jurisdiction based on the agreement in writing by the parties; the third one - jurisdiction of the court seized of a divorce (legal separation or marriage annulment) is accepted for the case on parental responsibility expressly or otherwise in an unequivocal manner by the spouses and by the holders of parental responsibility. These international treaties concretize provisions of p. 1 Art. 76 of the Law of Ukraine on Private International Law and make it possible to improve the practice of application of the rules on international jurisdiction by courts, attorneys and participants of family-law relations. However, many important issues concerning this type of jurisdiction require more detailed regulation on the national level. In the author's point of view, the major improvements that should be implemented in the Law of Ukraine on Private International Law deal with clarification of rules on prorogation of jurisdiction, such as the form of prorogation agreement, time of its concluding, effects of prorogation agreement and consequences of its breach.

\section{References}

ALI/UNIDROIT Principles of Transnational Civil Procedure as Adopted and Promulgated by the American Law Institute at Washington, D.C., U.S.A. May 2004 and by UNIDROIT at Rome, Italy April 2004. Cambridge University Press, 2006.

Case 150/80, Elefanten Schuh v. Jacqmain. ECR [1981], p. 01671.

Case 48/84, Spitzley v. Sommer. European Court reports [1985], p. 00787.

CIS Agreement on the Order for Resolution Disputes Arising from Economic Activity. March 20, 1992. Official Bulletin of Ukraine. 2005, No 12.

CIS Convention on Legal Assistance and Legal Relationships in Civil, Family and Criminal Matters. January 22,
1993. Official Bulletin of Ukraine. 2005, No 44.

Civil Procedural Code of Ukraine. March 18, 2004 [interactive]. [accessed on 2014-10-06]. <http://zakon4.rada.gov. ua/laws/show/1618-15>.

Commercial Procedural Code of Ukraine. November 6, 1991 [interactive]. [accessed on 2014-10-06]. <http:// zakon4.rada.gov.ua/laws/show/1798$12>$.

Convention of October 2, 1973 on the Recognition and Enforcement of Decisions Relating to Maintenance Obligations. 1021 UNTS 209.

Convention of October 19, 1996 on Jurisdiction, Applicable Law, Recognition, Enforcement and Co- 
operation in Respect of Parental Responsibility and Measures for the Protection of Children [interactive]. [accessed on 2014-10-06]. $<$ http://www.hcch.net/index_en. php? act $=$ conventions.text $\&$ cid $=70>$. Law of Ukraine on the Accession to the Convention (September 14, 2006). Bulletin of Verchovna Rada of Ukraine. 2006, No 43.

Convention of 30 June 2005 on choice of court agreements. [accessed 2014-10-06]. <http://www.hcch.net/ index_en.php?act=conventions.text $\&$ cid $=98>$.

Convention of 30 October 2007 on jurisdiction and the recognition and enforcement of judgments in civil and commercial matters (Lugano Convention). [2007] OJ of the EC, 21.12.2007.

Convention of 23 November 2007 on the International Recovery of Child Support and Other Forms of Family Maintenance. [accessed 2014-10-06]. <http://www.hcch.net/ index_en.php?act=conventions.text $\&$ cid $=38>$.

Decision of Oleksandrivskiy Local Court of Kirovograd Region from May, 13, 2013. Case № 398/3580/13-ц [interactive]. <http://reyestr.court.gov. $\mathrm{ua} />$.

Decision of Pecherskiy District Court in Kyiv from November, 22, 2010. Case № 2-8170/2010 [interactive]. <http:// reyestr.court.gov.ua/>.

Dovgert, A. C. Peredmova. Mizhnarodne privatne pravo. Naukovo-praktichij komentar Zakonu. / Za red. doktora juridichnikh nauk, prof. A. Dovgerta. [Dovgert, A.S. Introduction. Scientific and Practical Commentary on the Law of Ukraine on Private International Law. Dr. Prof. A. Dovgert (ed.)]. Kh.: TOV «Odisej», 2008.

Fentiman, R. International Commercial Litigation. Oxford University Press, 2010.

Kejlin, A. D. Sudoustrojstvo i grazhdanskij process kapitalisticheskikc gosudarstv. Ch. 2. [Keylin, A. D. Judicial System and Civil Procedure in Capitalistic States. P. 2]. Moskva: Vneshtorgizdat, 1958.

Kisil, V. I. Mizhnarodne privatne pravo: pitannja kodifikacii. [Kysil, V.I. Private International Law: Issues of Codification]. Kiiv: Ukraina, 2000.

Law of Ukraine on Foreign Economic Activity. April 16, 1991. Bulletin of Verkhovna Rada of Ukraine. 1991, No 29.

Law of Ukraine on Private International Law. June 23, 2005. Bulletin of Verkhovna Rada of Ukraine. 2005, No 32.

Law of Ukraine on the Ratification of the Convention. January 11, 2013. Official Bulletin of Ukraine. 2013, No 12.

Law of Ukraine on the Status of Judges and Judicial System of Ukraine. July 7, 2010 [interactive]. [accessed on 201410-06]. <http://zakon4.rada.gov.ua/ laws/show/2453-17>.

Lebedev, S. N. Priznanie prorogacionnykh uslovij sdelok $v$ mezhdunarodnoj torgovle. [Lebedev, S. N. Recognition of Prorogation Agreements in International Trade]. Sovietskij ezhegodnik mezhdunarodnogo prava, 1963. Moskva: Nauka, 1965, p. 420440.

Lebedev, S. N. Priznanie prorogacionnykh uslovij sdelok $v$ mezhdunarodnoj torgovle. [Boguslavskiy, M.M. Private International Law]. Moskva: Jurist, 1998. 
Lowel, N. The 1996 Hague Convention on the Protection of Children. Family Law. 2012.

Magnus, U.; Mankowski, P. European Commentaries on Private International Law. Brussels IIbis Regulation. SELP, 2012.

Mizhnarodnij civilnij proces Ukraini: Navchalnij posibnik. Praktikum: za red. S.Ja. Fursi. [International Civil Procedure of Ukraine: Textbook, Practicum. Fursa, S.Ya. (ed.)]. Kiiv: Vidavec Fursa S.Ja.: KNT, 2010.

Pointer, J.A.; Burg, E. EU Principles on Jurisdiction and Recognition and Enforcement of Judgments in Civil and Commercial Matters (According to the Case Law of the European Court of Justice). The Hague, The Netherlands: TMC Asser Press, 2004.

Regulation No 2201/2003/EC of November 27, 2003 Concerning Jurisdiction and the Recognition and Enforcement of Judgments in Matrimonial Matters and the Matters of Parental Responsibility, Repealing Regulation (EC) No. 1347/2000. [2003] OJ of the EU, L 338, Vol. 46, 23 December 2003.
Regulation No 4/2009/EC of December 18, 2008 on Jurisdiction, Applicable Law, Recognition and Enforcement of Decisions and Cooperation in Matters Relating to Maintenance Obligations. [2009] OJ of the EC, 10.1.2009.

Regulation No 44/2001/EC of December 22, 2000 on Jurisdiction and the Recognition and Enforcement of Judgments in Civil and Commercial Matters. [2001] OJ of the EC, 16.1.2001.

Shak, Kh. Mezhdunarodnoe grazhdanskoe procesualnoe pravo: Uchebnik. / Perevod s nemeckogo. [Shack, H. International Civil Procedural Law: Textbook (Translation from German)]. M.: Izdatelstvo BEK, 2001.

Smith De Bruin, B.L., M. Transnational Litigation. Jurisdiction and Procedure. Thomson Round Hall, 2008.

Steffek, F.; Unberath, U.; Genn, H.; Greger, R.; Menkel-Meadow, C. Regulating Dispute Resolution. ADR and Access to Justice at the Crossroads. Oxford and Portland, Oregon, 2013.

The Merchant Shipping Code of Ukraine. May 23, 1995. Bulletin of Verkhovna Rada of Ukraine. 1995, No 47.

\title{
SUSITARIMAI DĖL JURISDIKCIJOS ŠEIMOS TEISĖS BYLOSE: GALIOJANČIOS NACIONALINĖS TEISĖS IR UKRAINOS TARPTAUTINIŲ SUTARČIŲ ANALIZE்
}

\author{
Yuliya Chernyak \\ Kijevo nacionalinis Taraso Ševčenkos universitetas, Ukraina
}

Anotacija. Šiame straipsnyje pristatomi Ukrainos nacionaline teisè ir šios valstybés sudarytų tarptautinių sutarčiu jurisdikcijos nustatymo tyrimo rezultatai. Autoré daugiausia demesio skiria Hagos konvencijos del vaiku apsaugos taikymui ir prieina prie išvados, kad būtina plèsti jurisdikciją bylose, kylančiose iš šeimos teisinių santykių. 
Reikšminiai žodžiai: susitarimai dèl jurisdikcijos, šeimos teisès klausimai, Ukrainos teisèkūra, Hagos konvencija dèl tarptautinès vaikų apsaugos, Europos civilinis procesas.

\title{
PROROGATION OF JURISDICTION IN FAMILY-LAW MATTERS: ANALYSIS OF CURRENT NATIONAL LEGISLATION AND INTERNATIONAL TREATIES OF UKRAINE
}

\author{
Yuliya Chernyak
}

Kyiv National Taras Shevchenko University, Kyiv, Ukraine

Summary. This article examines whether the principle of party autonomy and prorogation of jurisdiction may be applied in cross-border litigation on family-law matters. Drawing different sources, including scientific works, national legislation of Ukraine, international treaties, instruments on codification of the principles on transnational civil procedure, the paper first gives a brief overview of the history and current situation concerning regulation of prorogation of jurisdiction. Then, the author presents the results of a study of jurisdictional rules provided by Ukrainian internal legal acts and international agreements on jurisdiction in which Ukraine is a party (the Hague Conventions, bilateral and multilateral treaties on legal assistance and legal relations in civil and family relations) and draws conclusions concerning peculiarities of prorogation of jurisdiction for matters arising from family-law relations. Attention is also paid to the comparative overview of the Hague Conventions and Regulations of the European Union (Regulation No 2201/2003/EC of November 27, 2003 Concerning Jurisdiction and the Recognition and Enforcement of Judgments in Matrimonial Matters and the Matters of Parental Responsibility and Regulation No 4/2009/EC of December 18, 2008 on Jurisdiction, Applicable Law, Recognition and Enforcement of Decisions and Cooperation in Matters Relating to Maintenance Obligations). Several opinions of the European Court of Justice on some issues of prorogation of jurisdiction are noted, as well.

The most remarkable changes in the prorogation agreements regulation in Ukraine took place by the entry into force in 2005 of the Law of Ukraine on Private International Law. Article 76 of the Law stipulates for the first instance when Ukrainian courts may initiate the proceedings and try cases with a foreign element the instance "if the parties chose the jurisdiction of Ukrainian courts over a case with a foreign element by their agreement". The Hague Conventions on jurisdiction and children protection in which Ukraine is a party (Convention of October 19, 1996 on Jurisdiction, Applicable Law, Recognition, Enforcement and Co-operation in Respect of Parental Responsibility and Measures for the Protection of Children and Convention of 23 November 2007 on the International Recovery of Child Support and Other Forms of Family Maintenance) concretize provisions of p. 1 Art. 76 of the Law of Ukraine on Private International and 
specify three variants of prorogation of jurisdiction in family-law matters. They are the following ones: (I) the respondent submits to the jurisdiction either expressly or by defending on the merits of the case without objecting to the jurisdiction; (II) jurisdiction based on the agreement in writing by the parties; (III) jurisdiction of the court seized of a divorce (legal separation or marriage annulment) is accepted for the case on parental responsibility expressly or otherwise in an unequivocal manner by the spouses and by the holders of parental responsibility.

Keywords: Prorogation of jurisdiction, family-law matters, legislation of Ukraine, The Hague Conventions on jurisdiction and children protection, European civil procedure.

Yuliya Chernyak, Kijevo nacionalinio Taraso Ševčenkos universiteto Tarptautinių santykių instituto Tarptautinès privatinès teisès katedros docentė, socialinių mokslų daktarè. Mokslinių tyrimų kryptys: tarptautinė privatinè teisé, tarptautinis civilinis procesas, notariniai procesai, įtraukiantys užsieniečius, tarptautinè šeimos teisè.

Yuliya Chernyak, Ph.D., Kyiv National Taras Shevchenko University, Department of Private International Law, Institute of International Relations, Associate Professor. Research fields: international private law, international civil process, notarial proceedings involving foreigners, international family law. 